\title{
Characterisation of Clinical Epidemiological Profile of Patients with Facial Lipoatrophy, Living with Aids, Submitted to Facial Filling with Polymethylmethacrylate
}

\section{Marcos Alberto Martins 1,2,4, Walter Henrique Martins 1,2,3,4, Karina Viviani de Oliveira Pessôa', Mariliza Henrique da Silva1, Gerson Vilhena Pereira Filho ${ }^{3}$ Italla Maria Pinheiro Bezerra ${ }^{2}$, Luiz Carlos de Abreu ${ }^{2,5}$}

\section{Abstract}

Background : Patients living with AIDS and on Antiretroviral Therapy are likely to develop Lipodystrophy Syndrome. Soft tissue filler with Polymethylmethacrylate is an option to treat Facial Lipoatrophy. It is a small procedure performed on an outpatient basis. Aimet to characterise the clinical and epidemiological profile of patients living with AIDS, who developed Facial Lipoatrophy and who underwent facial filler with Polymethylmethacrylate.

Methods: A descriptive, observational study with 63 patients with AIDS, Facial Lipoatrophy, submitted to facial filling with Polymethylmethacrylate. As sources for data collection, data were analysed from records, and the Protocol Lipodystrophy Ambulatory of the Municipal STD/AIDS and Viral Hepatitis of São Bernardo do Campo, in São Paulo, Brazil, of patients treated between January and July 2009.

Results: On average, HIV was diagnosed for 11.5 years, mean duration of antiretroviral therapy for 10 years and mean duration of 3.8 years for Facial Lipoatrophy. Most made use of Stavudine and/or Efavirenz. At the beginning of treatment, the mean dosage of CD4 was 284 cells $/ \mathrm{mm}^{3}$ and at the time of filling the average was 709 cells/ $\mathrm{mm}^{3}$. Cholesterol levels were elevated in $44.4 \%$, and the Triglycerides were elevated in $66.7 \%$. There were practically no adverse effects from the filling.
1 Programa Municipal de DST/AIDS e Hepatites Virais de São Bernardo do Campo, SP. Brasil.

2 Laboratório de Delineamento de Estudos e Escrita Científica. Departamento de Saúde da Coletividade. Disciplina de Metodologia Científica. Faculdade de Medicina do ABC. Santo André, SP. Brasil.

3 Disciplina de Cirurgia Plástica. Departamento de Cirurgia. Faculdade de Medicina do ABC. Santo André, SP. Brasil.

4 Serviço de Cirurgia Plástica. Hospital Samaritano de São Paulo.

5 Harvard T. H. Chan School of Public Health Department of Environmental Health.

\section{Contact information:}

Luiz Carlos de Abreu.

Laboratório de Delineamento de Estudos e Escrita Científica. Departamento de Saúde da Coletividade. Disciplina de Metodologia Científica.

Address: Faculdade de Medicina do ABC. Santo André, SP. Brasil. Av. Príncipe de Gales, 821, Santo André, SP CEP 09060 650.

Đ luiz.abreu@fmabc.br 
Conclusion: On average, HIV was diagnosed for 11.5 years, mean duration of antiretroviral therapy for 10 years and mean duration of 3.8 years for Facial Lipoatrophy.

\section{Keywords}

Antiretroviral Therapy; HIV; Lipodystrophy; Polymethylmethacrylate; Facial Lipoatrophy

\section{Introduction}

The Lipodystrophy Syndrome in HIVIAIDS (LDS) is characterised by bodily changes and metabolic changes in the body of the patient with HIVIAIDS and is associated with the use of High Active Antiretroviral Therapy (HAART). As a feature of this syndrome, in the peripheral areas of the body like the upper limbs, lower limbs, buttocks and face, fat loss occurs, called lipoatrophy, while in central areas such as breasts, abdomen, buffalo hump (the region just below the posterior base of the neck) and submental region volume increase occurs due to accumulation of fat, called Lipohypertrophy [1].

Initially, this syndrome was associated with the use of Antiretroviral Therapy (ART) and, in principle, to protease inhibitors (PI). Later, it was also associated with the use of reverse transcriptase inhibitors Nucleoside analogues (NRTIs). This latter category is most associated with Facial Lipoatrophy [2]. Over the years, it was found that Lipodystrophy also occurred in some patients who had never used HAART, suggesting the involvement of other mechanisms, such as inflammatory, environmental and genetic factors [2].

Part of the Lipodystrophy Syndrome is metabolic change, such as increased levels of Cholesterol, Triglycerides and Glucose [3-6].

In the face, Lipodystrophy is characterised by loss of fat, especially in malar regions (Bichat fat), preauricular and temporal region, which leaves a person emaciated-looking [7].

The effects of Lipodystrophy are irreversible and therapeutic options to treat these changes are often discussed, among which are repair surgeries able to minimise the effects. Brazil was a pioneer in offering free surgical repair for patients with HIVIAIDS who have Lipodystrophy $[8,9]$.

Soft tissue filler with Polymethylmethacrylate (PMMA) is the procedure adopted by the Ministry of Health in Brazil to treat Facial Lipoatrophy [10].

PMMA is a permanent filler, safe and produces immediate results. The application must be performed by skilled medical professionals [11].

These patients also suffer with emotional and psychiatric disorders, which cause a loss of self-esteem, family problems, social exclusion and, worse still, abandonment of treatment that can lead to disease progression [12-14].

Understanding, that the Facial Lipoatrophy is associated with retroviral AIDS treatment and it brings irreversible consequences to the patient syndrome and, in turn, physical and emotional changes, ask yourself: How will the clinical epidemiological profile of patients with Lipodystrophy Syndrome who underwent reconstructive surgery? Will these patients feel satisfied after surgery? Can complications related to this procedure occur?

To answer the questions, the present study aimed characterise the clinical-epidemiological profile of patients with Facial Lipoatrophy, living with AIDS, who submitted to facial filling with Polymethylmethacrylate and relate the occurrence of complications after the procedure.

\section{Methods}

A descriptive, observational, quantitative study with 63 patients with AIDS, Facial Lipoatrophy, who submitted to facial filling with Polymethylmethacrylate, in the Lipodystrophy Ambulatory of the Municipal 
Programme of Sexually Transmitted Diseases (STDs), AIDS and Viral Hepatitis (HV) of São Bernardo do Campo, São Paulo, Brazil. The sample consists of all patients who attended from January to July 2009, and met the inclusion criteria recommended in Ordinance No. 118 of 23 February, 2005, of the Ministry of Health in Brazil [9].

These inclusion criteria are: age between 18 and 72 years, both sexes, diagnosed with AIDS and Facial Lipoatrophy in outpatient treatment with antiretroviral drugs for a minimum period of 12 months, with levels of CD4 T-Lymphocytes (CD4) above 200 cells $/ \mathrm{mm}^{3}$ and plasma Viral Load of HIV (VL) preferably below 10.000 copies $/ \mathrm{mm}^{3}$.

Thus, as patients come to the clinic already taken by infectious disease screening, in other words, fit for the procedure, took part in this study all patients who arrived at the clinic during the period of collection established. It is noted that all were included in the inclusion criteria listed above.

This study was approved by the Research Ethics Committee of the Faculty of Medicine of $A B C$ registered under number 361/2008.

Patients were evaluated clinically by an infectious disease physician. Later, they were evaluated by a multidisciplinary team, to fill the Protocol of the Lipodystrophy Clinic of São Bernardo do Campo, in accordance with the resolution of the Brazilian Ministry of Health.

Before performing the procedure, patients were counselled about the treatment and signed the consent form. Photographic documentation was made in accordance with the standards of the Brazilian Association of Technical Standards.

As instruments for data collection and analysis questionnaire were used from the medical records, and the Protocol of Lipodystrophy Ambulatory of the Municipal STD/AIDS and Viral Hepatitis of São Bernardo do Campo, in São Paulo, Brazil, of all patients seen during the period January to July 2009 .

Regarding the variables studied include: gender, age and race. Medical-clinical criteria were: time of
HIV diagnosis, likely form of contagion, how long before the Facial Lipoatrophy appeared, usage time and number of changes of Antiretroviral Therapy (HAART), use of Stavudine (D4T) and Efavirenz (EFV).

We collected data from laboratory controls: level count of T-CD4 Lymphocytes (CD4) at the beginning of treatment with HAART at the time of the completion of facial filling and also the lowest and the highest value recorded; the level of Plasma Viral Load (CV) at the time of filling; dosage levels of Cholesterol, Triglycerides and Glucose in the blood; and the Body Mass Index (BMI) and Cardiovascular Risk, which was calculated by the FRAMINGHAM scale.

Finally, it was verified the occurrence of complications or adverse events related to the filling procedure or to the product used as filler. Descriptive analysis was performed using measures of central tendency, dispersion and tables of percentages.

\section{Results}

The sixty-three (63) patients with AIDS and Facial Lipoatrophy underwent facial filling with Polymethylmethacrylate and there was no sample loss. Tables 1 and $\mathbf{2}$ present data from epidemiological profile and related descriptive data.

Table 1. Characterisation of Facial Lipoatrophy patients living with AIDS who underwent facial filling with Polymethylmethacrylate (PMMA). São Bernardo do Campo-São Paulo, Brazil, 2009.

\begin{tabular}{|l|c|c|}
\hline \multicolumn{1}{|c|}{ Categories } & n & \% \\
\hline Sex & & \\
\hline Female & 20 & 31.8 \\
\hline Male & 43 & 68.2 \\
\hline Etnic group & & \\
\hline White & 63 & 100.0 \\
\hline Intercourse & 58 & 92.0 \\
\hline Injectable drugs & 4 & 6.5 \\
\hline Blood transfusion & 1 & 1.5 \\
\hline
\end{tabular}




\section{INTERNATIONAL ARCHIVES OF MEDICINE

Vol. 8 No. 120

doi: $10.3823 / 1719$

\begin{tabular}{|l|c|c|}
\multicolumn{1}{|c}{ Categories } & $\mathbf{n}$ & $\%$ \\
\hline Sexual Behaviour & & \\
\hline Homossexual & 18 & 28.6 \\
\hline Heterossexual & 45 & 71.4 \\
\hline Use of Stavudine and Efavirenz & & \\
\hline Stavudine (D4T) & 56 & 88.9 \\
\hline Efavirenz (EFZ) & 49 & 77.8 \\
\hline D4T e EFZ & 43 & 68.2 \\
\hline No use of D4T and EFZ & 1 & 1.5 \\
\hline Abnormal laboratory tests & & \\
\hline Total Cholesterol (CT) (mg/dl) & 28 & 44.4 \\
\hline Triglycerides (TG) (mg/dl) & 42 & 66.7 \\
\hline Glycemia (GL) (mg/dl) & 7 & 11.1 \\
\hline CT + TG (mg/dl) & 25 & 39.7 \\
\hline CT + TG + GL (mg/dl) & 3 & 4.8 \\
\hline Body Mass Index (BMl) & & \\
\hline Below Index & 4 & 6.3 \\
\hline Ideal & 42 & 66.7 \\
\hline Over Index & 16 & 25.4 \\
\hline Obese level I & 1 & 1.6 \\
\hline Cardiovascular risk (Framingham) & & \\
\hline Low & 39 & 61.9 \\
\hline High & 10 & 15.9 \\
\hline Moderate & 14 & 22.2 \\
\hline
\end{tabular}

\section{Discussion}

Regarding the AIDS diagnosis, according to the Epidemiological Bulletin AIDS and STD 2013,718,000 people living with HIVIAIDS in Brazil. Considering the accumulated data from 1980 to June 2013 in Brazil, a total of 686,478 cases were reported with AIDS, of whom 445,197 (64.9\%) were male and 241,223 patients (35.1\%) were female [15].

In this sample, 43 patients (68.2\%) are male and 20 patients (31.8\%) are female; the ratio was 2.15 males to one infected woman. Two factors seem to have influenced these indices: the first was the fact that this sample included only patients with loss of subcutaneous fat in the face, and, as previously mentioned, this is more common [16] among men; and, second, was the diagnosis timing of HIV infection, which ranged from 3 to 26 years, with an average of 11.55 years, standard deviation of 4.40 years. Therefore, it is a sample diagnosed long ago, at a time of highest incidence of HIV among men (Tables 1 and 2).

Over the past 10 years, from 2003 to 2012, were reported on average 37,446 AIDS cases per year, with an upward trend in Brazil as a whole. Regar-

Table 2. Measures of central tendency and dispersion of patients with Facial Lipoatrophy living with AIDS who underwent facial filling with Polymethylmethacrylate (PMMA). São Bernardo do Campo-São Paulo, Brazil, 2009.

\begin{tabular}{|c|c|c|c|c|}
\hline Category & Mean & Standard deviation & Minimum & Maximum \\
\hline Age (years) & 49.71 & 9.80 & 34 & 74 \\
\hline Timing of HIV (years) & 11.55 & 4.40 & 3 & 26 \\
\hline Timing of ART (years) & 10.03 & 3.33 & 3 & 20 \\
\hline Nr of changes of ART & 3.41 & 1.64 & 1 & 9 \\
\hline CD4 at filling (cells/mm³) & 709.12 & 362.07 & 200 & 1563 \\
\hline CD4 in the beginning (cells $/ \mathrm{mm}^{3}$ ) & 284.34 & 208.07 & 2 & 917 \\
\hline Bigger CD4 (cells/mm³) & 947.63 & 448.20 & 254 & 2271 \\
\hline Smaller CD4 (cells/mm³) & 212.80 & 143.36 & 2 & 634 \\
\hline Timing of Facial Lipoatrophy (years) & 3.80 & 2.59 & 1 & 10 \\
\hline Viral Load (copies/ml) & * & * & undetec-table & 57843 \\
\hline
\end{tabular}

* Unable to calculate mean and standard deviation to be undetectable when less than 40 copies $/ \mathrm{ml}$ 
ding gender, in 2012, the detection rate of AIDS cases in men was 26.1/100,000 inhabitants and 14.5 in women, with ratio sexes of 1.7 cases in men to women in each case [15].

With regard to the AIDS patients who developed Facial Lipoatrophy, although there are only a few studies relating to this type of Lipoatrophy, one study involving 62 patients in Spain showed a similar distribution to our findings: $71 \%$ male patients and the median age of 40 years [17].

Regarding sex, male patients have a greater tendency to develop Lipoatrophy compared with the opposite sex. Males seem to be more prone to loss of fat in peripheral regions, while females accumulate fat in the central regions [16].

In our sample, the youngest patient was 34 years old and the oldest was 74 years. The mean age was 49.71 years (table 2 ).

In this study (Tables 1 and 2), among women, the infection resulted from heterosexual contact with people infected with HIV (95\%) or from blood transfusion (5\%). Among men, $51.15 \%$ of cases resulted from heterosexual contact, 39.55\% from homosexual relationships and $9.3 \%$ from illicit drug injection. We had no case of vertical transmission.

In the Programme of STD/AIDS and Viral Hepatitis in São Bernardo do Campo, the frequency of Facial Lipoatrophy in Outpatient Lipodystrophy was $8.43 \%$ (table 1).

There is no consensus whether ethnicity affects the prevalence or characteristics of Lipodystrophy. The redistribution of fat seemed to be less prominent in African-Americans and Hispanics compared with Caucasians in the US. However, studies in Singapore, Japan and Nigeria showed similar prevalence rates in these three ethnic groups [18]. During the data collection phase of this study, $100 \%$ of patients with facial Lipoatrophy referred to the Ambulatory of Lipodystrophy were white (Table 1).

There is also no consensus on the incidence of Lipodystrophy in patients with AIDS; this value can vary from 6 to $69 \%$ among patients on Antiretroviral Therapy (ART) for at least one year. [19-23]

The prevalence of Lipodystrophy also varies widely, occurring in between 10 and $80 \%$ of patients. It is believed that this large variation may result from the absence of a consensual characterisation of the syndrome, leading to varied interpretations with low reproducibility and heterogeneous settings [24].

In convergence, there are studies suggesting that although the rates of incidence and prevalence of Facial Lipoatrophy vary, currently the incidence can be established between 7.3 to 11.7 per 100 patients/year and the estimated prevalence of $17 \%$ in adults receiving ART for a period less than one year and $43 \%$ when the use of ART is longer than a year $[3,5,21,25,26]$.

The count of CD4 T-Lymphocytes (CD4) is the best indicator of the immune system and also a predictor of opportunistic infections. It is, therefore, an examination of great value to the clinical management of patients conducted by infectologists. On the other hand, Plasma Viral Load (VL) shows how much the virus is reproducing in the body. The CD4 count and plasma viral load quantification are indicators for starting ART and prognostic parameters that monitor the evolution of the immune status of individuals [24].

Thus, as shown in Table 2, the mean CD4 count was 709 cells $/ \mathrm{mm}^{3}$ at the time of facial filling, 284 cells $/ \mathrm{mm}^{3}$ at the beginning of therapy with antiretroviral and the average of the lowest and highest values during treatment were, respectively, 212 cells/ $\mathrm{mm}^{3}$ and 948 cells $/ \mathrm{mm}^{3}$. The viral load was undetectable in $88.9 \%$ of patients at the time of facial filling. It was not possible to calculate mean and standard deviation, which is undetectable when less than 40 copies $/ \mathrm{ml}$.

The Caucasian patients above 40 years of age, infected with HIV for over 10 years, with baseline CD4 counts below 100 cells $/ \mathrm{mm}^{3}$ and who used Stavudine for any period, are more likely to develop some type of Lipodystrophy [27]. 
As we included in this study only patients with an indication for facial filling by inclusion criteria and safety of the procedure, necessarily needed to be in good clinical condition, this explains the high levels of CD4 and CV of this population. The low initial CD4 counts are related to the time of HIV diagnosis, which occurred when we awaited more critical indexes than current CD4 to start drug therapy.

As can be seen in this sample, the use of Antiretroviral Therapy is able to reverse the immune characterised by depletion of CD4 T-Lymphocytes (Table 2).

Initial therapy should always include combinations of three or four drugs. Antiretroviral therapy was highly effective in reducing the morbidity and mortality associated with infection by human immunodeficiency virus (HIV). Side effects for some patients on ART can induce severe metabolic complications such as insulin resistance (IR), Metabolic Syndrome (SM), Lipodystrophy (LDF) and Cardiovascular Disease (CVD). For this reason, controversy remains concerning the best time to start it.

Currently, the anticipation of starting ART in asymptomatic patients with CD4 around 350 cells/ $\mathrm{mm}^{3}$ has been the strategy used in the clinic to reduce the time of exposure to these drugs and their adverse effects. However, it is known that very low initial CD4 is associated with increased risk of Lipodystrophy [25, 27, 28].

Thus, individualization is a pressing factor in the relationship between doctor and patient. To agree with the patient the best initial antiretroviral regimen, the physician should consider: the ability to adhere to prescribed combination, the adequacy of routine, lifestyle and diet, potency and immediate and long-term toxicity of the treatment, the presence of other diseases besides AIDS, the use of other medications while using alcohol and illicit drugs.

In the assisted population, duration of use of HAART varied from 3 to 26 years, the average was 10.03 years with a standard deviation of 3.33 (Table
2). The HAART scheme was changed at least once and not more than nine times, with an average of 3.4 changes and standard deviation of 1.64 (Table 2). The long use of HAART and the number of changes may contribute to the development of Facial Lipoatrophy [29].

Several studies have linked the use of Stavudine (D4T), an inhibitor of Nucleoside Analog Reverse Transcriptase (NRTI), to the occurrence of Facial Lipoatrophy [5, 17, 21, 26]. Recently, Efavirenz (EFV) was also associated with the onset and progression of Lipoatrophy [24]. The adipocyte apoptosis appears to be related to the use of Protease Inhibitors $(\mathrm{PI})$, while the mitochondrial toxicity is more related to NRTI [30].

Of the two Lipodystrophy associated with antiretroviral drugs analysed in this study, Stavudine, although practically no longer used, showed a high utilisation rate for 56 patients (88.9\%). Efavirenz, a most recent antiretroviral and currently one of the drugs of first choice for starting treatment, was used for 49 patients (77.8\%) (Table 1). Notably, it was only in 2010 that the Ministry of Health in Brazil warned of the possibility that EFV causes Lipodystrophy [30].

The association of stavudine (D4T) with Efavirenz (EFV), weight loss up to seven $\mathrm{kg}$ and prolonged HIV infection appear to be significant factors that increase the risk of developing Lipoatrophy [5]. The use of two antiretroviral drugs was recorded in 43 patients (68.2\%) (Table 1).

Only one of the patients in this study had the same Facial Lipoatrophy having never used either of these two drugs (Table 1). It is also believed that HIV infection itself and not just the use of HAART is associated with Lipodystrophy [16].

So it is important to note that although there is a relationship between Lipodystrophy and initiation of treatment for AIDS using HAART, its occurrence is also observed without drug therapy, suggesting that both exhibit similar mechanisms of initiation [31]. 
The HAARTis also correlated with increased risk of cardiovascular morbidity, and Lipodystrophy, hyperCholesterolemia and lipid disorders in general. Dyslipidemia, in itself, increases the chances of cardiovascular dysfunctions [27].

Dyslipidemia, while clinical factors associated with HIV are increasingly present in people living with AIDS. There are common reports of changes in Blood Pressure Levels, Lipid Levels, Blood Glucose and increased Cardiovascular Risk [3-6, 27].

The HIV infection itself, as well as HAART, is associated with dyslipidemia. Soon after HIV infection the HDL Cholesterol decreases and Triglycerides (TG) increase, with decreased levels of total Cholesterol (TC) and HDL Cholesterol. With the introduction of HAART, there is gradual increase in the Total Cholesterol, HDL Cholesterol and Triglycerides, HDL Cholesterol remaining as before the antirretroviral medication [16]. Once antiretroviral treatment is initiated, between 33 and $82 \%$ of patients develop hyperCholesterolemia and 43 to 66\% have hypertriglyceridemia [24].

Adipose tissue has an important contribution in the clinical and Metabolic Syndrome, since the mechanisms of differentiation of adipocytes are the main targets of action of antiretroviral [24, 32].

In this sample of patients, Cholesterol levels were elevated in $44.4 \%$ and triglyceride levels in $66.7 \%$, and $39.7 \%$ had both Cholesterol and Triglycerides above the reference values (Table 1). Although no patient had diabetes prior to starting HAART, the glycemia was above the reference value in $11.1 \%$ of patients. In $4.8 \%$, changes were found in the results of these three tests: Cholesterol, Triglycerides and Glucose (table 1).

Cardiac Dysfunction in HIV infection was first described by Autran et al. (1983) to report a case of Kaposi's sarcoma of infarction in a patient with AIDS. Since then, there has been observed, especially in autopsies, $28 \%$ to $73 \%$ prevalence of cardiac involvement in HIV patients, with involvement of the pericardium, endocardium, myocardium and vessels [33, 34].

The use of protease inhibitors was associated with a higher prevalence of carotid artery lesions [26]. In this study, the Cardiovascular Risk in patients with Facial Lipoatrophy living with AIDS was estimated by the FRAMINGHAM risk score for cardiovascular disease, and 61.9\% were low risk, $22.23 \%$ moderate risk and $15.87 \%$ high risk (Table 1).

This scale was used following the recommendation of the Ministry of Health for monitoring of patients with AIDS in use of antiretroviral therapy, to predict the risk of myocardial infarction occurring in this population over 10 years [24].

Regarding the Body Mass Index (BMI), 6.3\% of patients are below the standard index, $66.7 \%$ normal, 25.4\% with an index above normal and $1.6 \%$ were classified as obese grade I (Table 1). $\mathrm{BMI}$, although it is not a parameter considered by the FRAMINGHAM scale, when outside the normal range may contribute to the worsening of health status of patients.

The change of medication, although this does not promote the recovery of lost fat in the face, can help control dyslipidemias often associated with these patients [3].

Certain surgical procedures may reduce the morphological changes in areas affected by Facial Lipoatrophy [25], thus preventing the patient from abandoning the treatment with antiretroviral drugs.

Around the world, various skin fillers are approved and used for the correction of Facial Lipoatrophy in people living with AIDS. The most frequently reported in the literature are Polylactic Acid, Polymethylmethacrylate, Hyaluronic Acid and Polyacrylamide, all of which have positively impacted the quality of life of patients [7, 35-39].

Study in Montreal (Quebec) revealed that Facial Lipoatrophy had forced them into a situation of intense vulnerability by making them recognizable as persons living with HIVIAIDS and discreditable in the 
eyes of others. In this sense, they were willing to go to great lengths to restore their facial features and regain a sense of normalcy [40].

In Brazil, with the objective of improving the quality of life of patients and thus encourage adherence to treatment, the Ministry of Health provides, through SUS (Brazilian public health system), the possibility of facial filling with Polymethylmethacrylate (PMMA) for people living with AIDS, in the presence of HAART for at least one year and who have Facial Lipoatrophy. The Ministry of Health in Brazil also states that this procedure should be performed by physicians with expertise in plastic surgery or dermatology.

Metacril ${ }$, Polymethylmethacrylate manufactured by Nutricell Laboratory, is the product supplied by the State Coordination (Reference and Training Centre in STD/AIDS in São Paulo) for facial filling. It is a composite of microspheres with diameters larger than 30 microns. These microspheres are present in suspension in a colloid medium of carboxy methyl cellulose which serves as a vehicle loader. The diameter of the microspheres is larger than the size of macrophage, which prevents them from being phagocytised.

After its injection, the colloid is absorbed by the body. Then, there is the proliferation of fibroblasts leading to microencapsulation of microspheres with small foreign body reaction, which prevents their migration. This can be observed on histological examination. Such characteristics make the PMMA a biocompatible filler, permanent and capable of promoting long results8.

The polymethylmethacrylate was chosen as filler for Facial Lipoatrophy to patients living with AIDS after 10 years of follow up, because it is a safe product, involving a relatively simple method of implementation and the most cost-effective when compared with other skin fillers [8].

There are few studies reporting adverse effects related to the use of PMMA $[12,41]$.

The side effects associated with various types of fillers, when they occur, are swelling, bruising, redness, pain, nodules or micronodules palpable in the subcutis, but not visible and usually disappear spontaneously within a short period of time [35, 37, 38, 42-44].

In malar and submalar regions they are nodules, granulomas and hyperemia [45, 46].

In this study, adverse effects, when they occurred, were transient, and $4.8 \%$ had marked local edema shortly after completion and 19\% had ecmose in the region of infraorbital nerve block, which disappeared within 7 to 14 days (Table 1). The microcannula is longer than the needle, which means that filling can be performed with a small number of punches and a lower injection pressure. With its atraumatic tip, blood vessel injury or change of plan completion is more difficult to occur, which makes the procedure safer, with less risk bruising, edema and pain [47]. With the microcannula, there is also less risk that the injection of the product occurs within the blood vessel, which could lead to emboli with subsequent tissue necrosis. Another factor that contributed to the low incidence of adverse events in this study was the training prior to the procedure which is required of plastic surgeons by the Ministry of Health.

Study in Hospital Universitário da Universidade Federal de Juiz de Fora (HU-UFJF) and at the Plastic Center Clinic, Plastic Surgery Clinic in Juiz de Fora, Brazil, Forty-one patients with Facial Lipoatrophy received filling with polymethylmethacrylate (PMMA), and presented as complications and complications presented as local inflammation and nodules [48].

In a study conducted at the Regional Hospital of Sorocaba, Brazil, with 46 HIV positive patients, who presented Facial Lipodystrophy in $12 \%$ of patients, the presence of small hematomas due to puncture, which spontaneously observed. Facial edema was observed in only one case, which also resolved spontaneously [49].

Thus, understanding and describing the clinical and epidemiological profile of this population 
allows guiding and directing multidisciplinary teams of Programmes and other official bodies in the area of Public Health in developing more effective strategies for prevention, control and rehabilitation of these patients.

In conclusion, patients were predominantly male, white and heterosexual, with mean age of 49.7 years. The main mode of transmission was sexual contact. On average, HIV was diagnosed for 11.5 years, mean duration of antiretroviral therapy for 10 years and mean duration of 3.8 years for Facial Lipoatrophy. Most made use of Stavudine and/or Efavirenz. At the beginning of treatment, the mean dosage of CD4 was 284 cells $/ \mathrm{mm}^{3}$ and at the time of facial filling the average was 709 cells/ $\mathrm{mm}^{3}$. The viral load was undetectable in $88.9 \%$ of patients. Cholesterol levels were elevated in $44.4 \%$, and the Triglycerides were elevated in $66.7 \%$. Blood Glucose was elevated in $11.1 \%$ of patients; $38.1 \%$ had moderate or high cardiovascular risk and $66.7 \%$ presented ideal weight of BMI. There were practically no adverse effects from the filling.

\section{Competing interests}

The authors declare that they have no competing interests.

\section{Authors'contributions}

Martins MA, Martins WH, Pessôa KVO, Silva $\mathrm{MH}$ participated in the acquisition of data and revision of the manuscript. All authors determined the design, interpreted the data and drafted the manuscript. All authors read and gave final approval for the version submitted for publication.

\section{References}

1. Carr A, Samaras K, Burton S, Law M, Freund J, Chisholm DJ, et al.: A syndrome of peripheral lipodystrophy, hyperlipidaemia and insulin resistance in patients receiving HIV protease inhibitors. AIDS. 1998 May 7, 12(7): F51-8.

2. Carr A, Samaras K, Thorisdottir A, Kaufmann GR, Chisholm DJ, Cooper DA. Diagnosis, prediction, and natural course of HIV1 protease-inhibitor-associated lipodystrophy, hyperlipidaemia, and diabetes mellitus: a cohort study. Lancet. 1999 Jun 19, 353(9170): 2093-9.

3. Panse I, Vasseur E, Raffin-Sanson ML, Staroz F, Rouveix E, Saiag P. Lipodystrophy associated with protease inhibitors. Br J Dermatol. 2000 Mar, 142(3): 496-500.

4. Hirsch HH, Battegay M. [HIV-infection, HAART (highlyactive antiretroviral therapy) and hyperlipidemia]. Dtsch Med Wochenschr. 2003 May 9, 128(19): 1051-4.

5. Bergersen BM, Sandvik L, Ellingsen I, Bruun JN. Lipoatrophic men 44 months after the diagnosis of lipoatrophy are less lipoatrophic but more hypertensive. HIV Med. 2005 Jul, 6(4): 260-7.

6. Lassalle S, Cervera P, Hofman V, Mari M, Dellamonica P, Hofman P. [Antiretroviral treatments-related Lipodystrophy Syndrome: clinico-pathological findings]. Ann Pathol. 2005 Sep, 25(4): 30917.

7. Loutfy MR, Raboud JM, Antoniou T, Kovacs C, Shen S, Halpenny $\mathrm{R}$, et al. Immediate versus delayed polyalkylimide gel injections to correct facial lipoatrophy in HIV-positive patients. AIDS. 2007 May 31, 21(9): 1147-55.

8. Ministério da Saúde do Brasil: Tratamento da Lipoatrofia Facial: Preenchimento com PMMA [http://www.crt.saude.sp.gov.br/ resources/crt aids/arquivosbibliotecacrt/artigospdfcompletos/ manual de tratamento da lipoatrofia facil.pdf]

9. Portela MC, Lotrowska M. Assistência aos pacientes com HIV/ Aids no Brasil. Rev Saúde Pública 2006, 40(Supl): 70-9.

10. Ministério da Saúde do Brasil: Portaria n 118 de 23 de fevereiro de 2005 [http://www.brasilsus.com.br/legislacoes/sas/4084$118]$

11. Ministério da saúde do Brasil. Secretaria de Vigilância a saúde. Departamento de DST, AIDS e Hepatites Virais. Manual de tratamento de lipoatorfia facial: recomendações para o preenchimento facial com Polimetilmetacrilato em portadores de HIVIAIDS. Brasília; 2009.

12. Alencar R, Caraciolo J, Fonsi $M$, et al.: Lipodystrophy: challenge and solutions [http://periodicos.ses.sp.bvs.br/scielo. php?script=sci arttext\&pid=S1806-42722010000200004\&Ing $=\mathrm{pt} \& \mathrm{nrm}=\mathrm{iso}]$

13. O'Brien KK, Bayoumi AM, Strike C, Young NL, Davis AM. Exploring disability from the perspective of adults living with HIVIAIDS: development of a conceptual framework. Health Qual Life Outcomes. 2008, 6: 76. 
14. Tran BX, Ohinmaa A, Nguyen LT. Quality of life profile and psychometric properties of the EQ-5D-5L in HIV/AIDS patients. Health Qual Life Outcomes. 2012, 10: 132.

15. Ministério da Saúde do Brasil: Boletim Epidemiológico Aids e DST 2013 [http://www.aids.gov.br/publicacao/2011/boletim epidemiologico 2013]

16. Martinez TLR. Alterações metabólicas presentes na infecção pelo HIV - revisão atualizada da sua etiopatogenia e tratamento. Rev Atividade Científica. 2008, 3(29): 3-1815.

17. Ribera E, Paradineiro JC, Curran A, Sauleda S, Garcia-Arumi E, Castella $E$, et al. Improvements in subcutaneous fat, lipid profile, and parameters of mitochondrial toxicity in patients with peripheral lipoatrophy when Stavudine is switched to tenofovir (LIPOTEST study). HIV Clin Trials. 2008 Nov-Dec, 9(6): 407

18. Paton, NI, Earnest A et al. Lipodystrophy in a cohort of human immunodeficiency virus-infected Asian patients: prevalence, associated factors, and psychological impact. Clin Infect Dis, v.35, n.10, 2002 Nov 15, p.1244-9.

19. Talmor M, Hoffman LA, LaTrenta GS. Facial atrophy in HIVrelated fat redistribution syndrome: anatomic evaluation and surgical reconstruction. Ann Plast Surg. 2002 Jul, 49(1): 11-7; discussion 117-8.

20. Abood A, Ong J, Withey S, Johnson M, Butler P. Facial atrophy in HIV-related fat redistribution syndrome: a plastic surgical perspective on treatment options and a look to the future. Int $J$ STD AIDS. 2006 Apr, 17(4): 217-20.

21. Fuller J. A 39-year-old man with HIV-associated lipodystrophy. JAMA. 2008 Sep 3, 300(9): 1056-66.

22. Peterson S, Martins CR, Cofrancesco J. Lipodystrophy in the patient with HIV: social, psychological, and treatment considerations. Aesthet Surg J. 2008 Jul-Aug, 28(4): 443-51.

23. Hornberger J, Rajagopalan R, Shewade A, Loutfy MR. Cost consequences of HIV-associated lipoatrophy. AIDS Care. 2009 May, 21(5): 664-71

24. Ministério da Saúde do Brasil: Síndrome Lipodistrófica. [http://www.crt.saude.sp.gov.br/resources/crt aids/ arquivosbibliotecacrt/artigospdfcompletos/manual_de tratamento_da_lipoatrofia_facil.pdf]

25. Luther J, Glesby MJ. Dermatologic adverse effects of antiretroviral therapy: recognition and management. Am J Clin Dermatol. 2007, 8(4): 221-33.

26. Joly $V$, Flandre $P$, Meiffredy $V$, Leturque $N$, Harel M, Aboulker $J P$, et al. Increased risk of lipoatrophy under Stavudine in HIV-1infected patients: results of a substudy from a comparative trial. AIDS. 2002 Dec 6, 16(18): 2447-54.

27. Pereira SBG, Gastaldi BS: Prevalência. In Lipodistrofia. 1 ed. Edited by Pereira SBG. São Paulo: Livraria Santos Editora Ltda; 2007: 9-11.

28. Behrens G, Schmidt RE. Lipodystrophy Syndrome. Flying Publisher. 2005 [http://bvsms.saude.gov.br/bvs/publicacoes/ hivmedicine2006.pdf]
29. Miller J, Carr A, Emery S, Law M, Mallal S, Baker D, et al. HIV lipodystrophy: prevalence, severity and correlates of risk in Australia. HIV Med. 2003 Jul, 4(3): 293-301.

30. Ministério da Saúde do Brasil: Boletim Epidemiológico Aids 2010 [http://www.aids.gov.br/sites/default/files/anexos/ publicacao/2010/45974/vers o final 15923.pdf]

31. Ministério da Saúde do Brasil: DST, Aids e Hepatites virais. Brasília; 2013.

32. Moyle G, Sutinen J. Managing HIV lipoatrophy. Lancet. 2004 Feb 7, 363(9407): 412-4.

33. D’Ámati G, Di Gioia CR, Gallo P. Pathological findings of HIVassociated cardiovascular disease. Ann NY Acad Sci 2001, 946: 23-45.

34. Barbaro G, Di Lorenzo G, Grisorio B, Barbarini G. Cardiac involvement in the acquired immunodeficiency syndrome: a multicenter clinical-pathological study. Gruppo Italiano per lo Studio Cardiologico dei pazienti affetti da AIDS Investigators. AIDS Res Hum Retroviruses. 1998 Aug 10, 14(12): 1071-7.

35. Valantin MA, Aubron-Olivier C, Ghosn J, Laglenne E, Pauchard M, Schoen H, et al. Polylactic Acid implants (New-Fill) to correct facial lipoatrophy in HIV-infected patients: results of the openlabel study VEGA. AIDS. 2003 Nov 21, 17(17): 2471-7.

36. Mest DR, Humble G. Safety and efficacy of poly-L-lactic acid injections in persons with HIV-associated lipoatrophy: the US experience. Dermato/ Surg. 2006 Nov, 32(11): 1336-45.

37. El-Beyrouty C, Huang V, Darnold CJ, Clay PG. Poly-L-lactic acid for facial lipoatrophy in HIV. Ann Pharmacother. 2006 Sep, 40(9): 1602-6

38. Kavouni A, Catalan J, Brown S, Mandalia S, Barton SE. The face of HIV and AIDS: can we erase the stigma? AIDS Care. 2008 Apr, 20(4): 485-7.

39. Bechara FG, Gambichler T, Brockmeyer NH, Sand M, Altmeyer $P$, Hoffmann K. Hyaluronic acid new formulation: experience in HIV-associated facial lipoatrophy. Dermatology. 2008, 217(3): 244-9.

40. Gagnon M. Understanding the experience of reconstructive treatments from the perspective of people who suffer from facial lipoatrophy: A qualitative study. International Journal of Nursing Studies, 2011 Nov 30.

41. Vargas $K F$, Borghetti $R L$, Moure $S P$, et al. Use of polymethylmethacrylate as permanent filling agent in the jaw, mouth and face regions - implications for dental practice. Gerodontology. 2011 Apr 4.

42. WHO. Report on the global AIDS epidemic, Executive Summary. 2008 [http://data.unaids.org/pub/GlobalReport/2008/jc1511_ gr08_executivesummary_en.pdf]

43. Negredo E, Puig J, Aldea D, Medina M, Estany C, Perez-Alvarez $\mathrm{N}$, et al. Four-year safety with polyacrylamide hydrogel to correct antiretroviral-related facial lipoatrophy. AIDS Res Hum Retroviruses. 2009 Apr, 25(4): 451-5. 
44. Matos AC, Boletini RS, Kating TC, Matsumoto NF, Gandolpho MA. Treatment of facial lipoatrophy in people infected by HIV/ AIDS: moving away from prejudice and improving quality of life. Mundo da Saúde 2010, 34(2): 210-7.30. Waitzberg DLK. Dieta, nutrição e câncer. In: Atheneu, editor. 2004: 618-24.

45. Castro AC, Collares MV, Portinho CP, Dias PC, Pinto RA. Extensive facial necrosis after infiltration of polymethylmethacrylate. Braz J Otorhinolaryngol. 2007 Nov-Dec, 73(6): 850.

46. Salles AG, Lotierzo PH, Gemperli R, Besteiro JM, Ishida LC, Gimenez RP, et al. Complications after polymethylmethacrylate injections: report of 32 cases. Plast Reconstr Surg. 2008 May, 121(5): 1811-20.

47. Niamtu J, 3rd. Filler injection with micro-cannula instead of needles. Dermato/ Surg. 2009 Dec, 35(12): 2005-8.

48. Dornelas MT et al. Bioplasty for lipodystrophy in patients with HIVIAIDS. Rev Bras Cir Plást. 2012; 27(3): 387-91

49. Rogowska-Szadkowska D, Chlabicz S, Oltarzewska MA, Sawicka-Powierza J. Which factors hinder the decision of Polish HIV-positive patients to take up antiretroviral therapy? AIDS Care. 2009 Mar, 21(3): 280-3.

50. Quintas RC, de França ER, de Petribú KC, Ximenes RA, Quintas LF, Cavalcanti EL, Kitamura MA, Magalhães KA, Paiva KC, Filho DB. Treatment of facial lipoatrophy with polymethylmethacrylate among patients with human immunodeficiency virus/acquired immunodeficiency syndrome (HIV/AIDS): impact on the quality of life. Int J Dermatol. 2014 Apr; 53(4): 497-502.

\section{Comment on this article:}

\section{(f) $(3)$ in $8+\mathbf{S} P$}

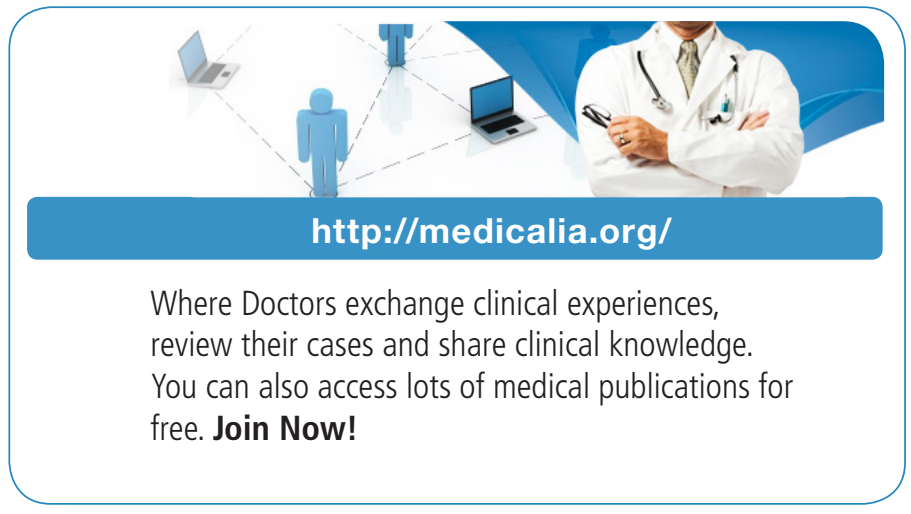

\section{Publish with iMedPub}

\section{http://www.imed.pub}

International Archives of Medicine is an open access journal publishing articles encompassing all aspects of medical science and clinical practice. IAM is considered a megajournal with independent sections on all areas of medicine. IAM is a really international journal with authors and board members from all around the world. The journal is widely indexed and classified Q1 in category Medicine. 